GLÁUKS

\title{
Entrevista com Noemi Jaffe
}

Joelma Santana Siqueira (Universidade Federal de Viçosa)

Vivaldo Andrade dos Santos (Georgetown University)

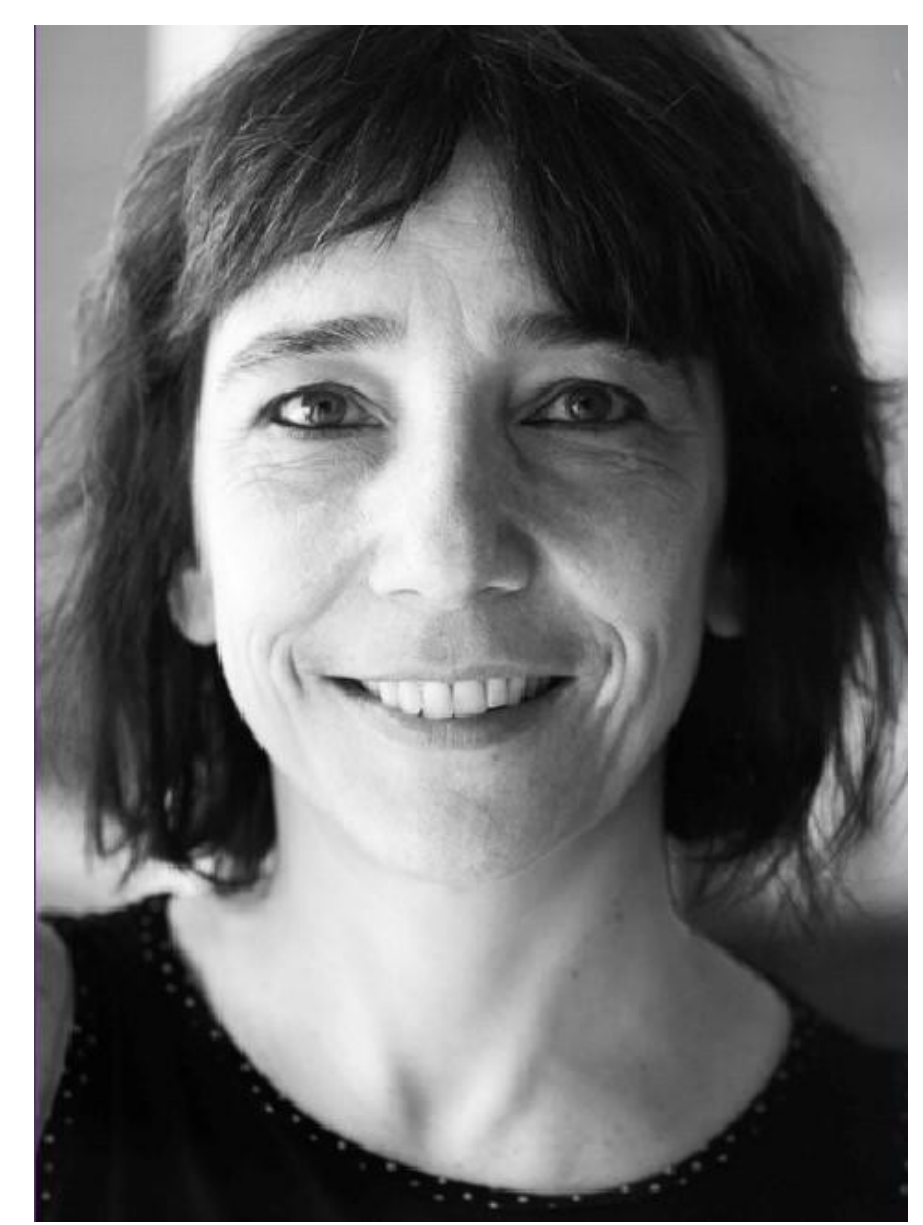

Fonte: Site $<$ https://www.companhiadasletras.com.br/autor.php?codigo $=03341>$.

Noemi Jaffe - Escritora, poeta, crítica e professora. Formada em Letras pela Universidade de São Paulo, atuou como professora de literatura brasileira no ensino fundamental de 1987 a 2008. Em 2001, publicou Folha Explica Macunaíma. Seu primeiro livro de poemas foi a coletânea Todas as Coisas Pequenas, lançado em 2005. Atualmente, dá aulas de escrita

Gláuks: Revista de Letras e Artes -/dez. 2020 - v. 20, n. 2 
criativa na Casa do Saber, no curso de Formação de Escritores do Instituto Vera Cruz, além de manter vários grupos particulares. Também trabalha como crítica literária para o jornal Folha de S.Paulo. Publicou também as obras Quando nada está acontecendo (Martins, 2011), O que os cegos estão sonhando? (Ed. 34, 2012), A verdadeira história do alfabeto (Companhia das Letras, 2012) e Írisz: as orquídeas (Companhia das Letras, 2015). Ganhou o Prêmio Brasília de Literatura de 2014 com o livro A verdadeira história do alfabeto.

1. Prezada Noemi Jaffe, somos muito gratos a você por nos conceder essa entrevista para o presente dossiê da Gláuks dedicado ao tema "A literatura brasileira no exterior". Para iniciarmos, pedimos que nos fale sobre como é escrever e publicar literatura no Brasil.

Como vocês devem saber, não é uma tarefa fácil. Há muito poucos leitores no país, os livros são caros e a educação está sempre em situação precária. Além disso, com o governo atual, cessaram as compras feitas pelo governo e agora, com a pandemia, as editoras e livrarias também estão em situação crítica. Mesmo assim, nossa literatura floresce, com festivais, eventos, editoras e autores independentes e muita coisa boa saindo todos os anos, inclusive com premiações de alto nível. Todos os escritores brasileiros, entretanto, precisam de outras fontes de renda - como aulas, palestras, jornais - para sobreviver.

2. Você considera que há diferenças que mereçam ser destacadas entre a recepção que sua obra tem no Brasil e a que tem no exterior?

Tenho muito poucas traduções no exterior e, por isso, nem tenho como fazer essa comparação.

Gláuks: Revista de Letras e Artes -/dez. 2020 - v. 20, n. 2 
3. Qual a importância da tradução, sobretudo, para o escritor que escreve em português?

Acho fundamental, especialmente porque nossa literatura é muito pouco conhecida fora do Brasil, em função do português ser uma língua ainda pouco apreciada e lida no mundo. Ultimamente tem havido um interesse maior, por causa de Clarice Lispector e novamente Machado de Assis e isso é animador. Vários autores brasileiros têm sido traduzidos e, para esses, também é importante ter essa receptividade fora do Brasil, mesmo que os números nunca sejam muito significativos, com algumas exceções, como a de Luiz Ruffato, na Alemanha.

\section{Quais são os desafios para ser publicada no exterior ou ser traduzida para outra} língua?

É preciso, em primeiro lugar, ter um bom agente - o que não é fácil - e que ele seja ativo e com contatos no exterior. Além disso, é preciso também interesse das editoras estrangeiras na literatura brasileira, sem que, para isso, ela precise ser folclórica, exótica ou regionalista. Não é fácil.

5."Traduttore, traditore”. Como é ler sua obra em outro idioma? Poderia nos dar algum exemplo?

Gostei muito de lê-la em inglês e fiquei muito satisfeita com a tradução de Julia Sanchez, que, aliás, é brasileira. Não tenho exemplos de casos que me surpreenderam ou frustraram.

Gláuks: Revista de Letras e Artes -/dez. 2020 - v. 20, n. 2 
6. Existe uma "literatura nacional", presa a um país, a uma região, a uma língua?

Espero que isso exista cada vez menos, porque as literaturas, como os países e línguas, estão se diversificando e se misturando. Existe uma literatura escrita em português do Brasil e ela tem suas especificidades linguísticas e contextuais, mas espero que jamais "presa" ao país, à região ou à língua. As vozes locais podem e devem ser traduzidas, mesmo que isso represente grande dificuldade.

\section{Seu fazer literário busca responder a alguma urgência presente na realidade social brasileira que você gostaria de destacar?}

Acredito que, por ser uma pessoa muito interessada na política brasileira, especialmente nesse momento de ameaça de nova ditadura, é difícil que isso não se reflita nos meus livros, textos e publicações, de forma mais ou menos direta. Em meu último livro, por exemplo, eu falo sobre a ditadura stalinista, mas todos podem perceber o quanto ela se aproxima do totalitarismo que nos ameaça no país. E isso acontece com tudo o que escrevo, sempre premido pelas circunstâncias subjetivas e objetivas da minha vida, que podem ser percebidas de forma mais simbólica e poética ou então de forma mais militante, dependendo do tipo de texto.

Gláuks: Revista de Letras e Artes -/dez. 2020 - v. 20, n. 2 